\title{
Population Growth and Damage Caused by Rhopalosiphum padi (L.) (Hemiptera, Aphididae) on Different Cultivars and Phenological Stages of Wheat
}

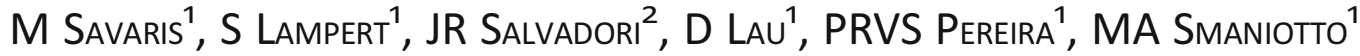 \\ ${ }^{1}$ Embrapa Trigo, Lab de Entomologia, Passo Fundo, RS, Brasil \\ ${ }^{2}$ Univ de Passo Fundo, Fac de Agronomia e Medicina Veterinária, Passo Fundo, RS, Brasil
}

\section{Keywords}

Aphids, damage, Triticum aestivum, yield

\section{Correspondence}

PRVS Pereira, Embrapa Trigo, Lab de Entomologia, Caixa Postal 451, CEP 99001-970, Passo Fundo, RS, Brasil; paulo.pereira@embrapa.br

Edited by Jorge B Torres - UFRPE

Received 22 June 2012 and accepted 29 July 2013

Published online: 29 August 2013

(C) Sociedade Entomológica do Brasil 2013

\begin{abstract}
Among the aphids associated with wheat and other winter cereals, Rhopalosiphum padi (L.) is currently the predominant species in the wheat growing region of southern Brazil. The damage caused by this aphid occurs by direct feeding and/or by the transmission of pathogenic viruses, such as the Barley/Cereal yellow dwarf virus. In order to estimate the direct damage caused by $R$. padi on wheat, we evaluated the population growth of this aphid during the tillering and elongation stages and its effects on grain yield components. The experiment was conducted in a screenhouse with three wheat cultivars (BRS Guabiju, BRS Timbaúva, and Embrapa 16). The effect of a period of 16 days, starting from an infestation of 40 aviruliferous aphids/plant, was evaluated and compared to non-infested plants. In both stages, the population growth of $R$. padi was lower on the BRS Timbaúva. Although infestation caused a reduction in the grain yield of the three cultivars, this effect was lower for BRS Timbaúva. The cultivar Embrapa 16 supported higher infestations and was more tolerant to damage than the BRS Guabiju.
\end{abstract}

\section{Introduction}

Aphids are important pests of wheat as they cause direct (feeding) and indirect damages by vectoring viruses that cause yellow dwarf in winter cereals (Barley yellow dwarf virus -BYDV and Cereal yellow dwarf virus-CYDV) (Gassen 1984, Salvadori 2000, Salvadori \& Tonet 2001, Parizoto et al 2013).

The most common and economically important aphid species associated with wheat in Brazil are the rose grass aphid, Metopolophium dirhodum (Walter), the greenbug, Schizaphis graminum (Rondani), the grain aphid, Sitobion avenae (Fabricius), and the bird cherry-oat aphid, Rhopalosiphum padi (Linnaeus) (Salvadori \& Tonet 2001, Salvadori \& Salles 2002, Salvadori et al 2006). Rhopalosiphum maidis (Fitch), Rhopalosiphum rufiabdominalis (Sasaki), Sipha maydis (Passerini), and Sipha flava (Forbes) are less frequent, but they also have some economic impact (Pereira et al 2008, Parizoto et al 2013).

The current population profile of wheat aphids differ from that of the past decades (1970-1990). In recent years, $R$. padi has become the most frequent species on this crop, and is abundant throughout all developmental stages of wheat plants (Salvadori \& Tonet 2001, Parizoto et al 2013).

The intensity of the damage caused by $R$. padi on wheat varies depending on several factors. Among them, we highlight the growth stages of wheat, influenced by the number of aphids per unit of time (aphid-days) (Kieckhefer \& Kantack 1988), where the initial stages are more susceptible to injury (Voss et al 1997, Gomes et al 2008). Recently, it was found that the Brazilian commercial wheat genotypes have different levels of resistance to $R$. padi (Peruzzo et al 2007). However, due to a lack of specific knowledge, the recommendations for aphid control on wheat are broad and do not 
take into account the effects that different plant genotypes have on pest population growth (RCBPTT 2010).

In here, we quantified the population growth of $R$. padi and its effect on the yield components of three wheat cultivars with different levels of resistance, when infested during two growth stages of the plant.

\section{Material and Methods}

Two experiments were conducted at the National Wheat Research Center-"Embrapa Trigo" in Passo Fundo, RS, Brazil, from June to November, 2009. In these experiments, the population growth of $R$. padi was evaluated using distinct sets of plants. In one of them, infestation occurred only in the tillering stage and in the other only in the elongation stage, corresponding, respectively, to the phenological stages four and six in the Feek scale modified by Large (1954). In both experiments, three wheat cultivars produced by the breeding program of "Embrapa Trigo", with different levels of resistance to $R$. padi were evaluated (BRS Guabiju and Embrapa 16-susceptible and BRS Timbaúva-resistant) (Peruzzo et al 2007, Cezare et al 2011). A set of 10 pots (replicates) was infested with 40 aviruliferous aphids/plant for each cultivar. The population was allowed to grow for a period of 16 days. Another set of 10 non-infested pots served as control in order to measure the yield potential of each cultivar, in the same conditions in which these experiments were conducted.

The experiments were carried out in a screenhouse and the $7.5 \mathrm{~L}$ experimental units $(24 \mathrm{~cm}$ high $\times 35 \mathrm{~cm}$ in diameter). The soil was fertilized with $250 \mathrm{~kg} \mathrm{ha}^{-1}$ of the formula 525-25 (N- $\left.\mathrm{P}_{2} \mathrm{O}_{5}-\mathrm{K}_{2} \mathrm{O}\right)$, and seeds were treated with the fungicide difeconazole (15\%) at a dose of $2 \mathrm{~mL} / \mathrm{kg}$ of seeds. Sixteen seeds were sown on the soil surface and then covered with $2 \mathrm{~cm}$ of sieved soil. Ten days after emergence, the weeds were eliminated, and the wheat plants were thinned out. Four evenly spaced plants were left per experimental unit.

The insects used in the experiment were collected in the field and kept on oat plants (Avena strigosa). To obtain aviruliferous aphids, recently born nymphs were collected just before they were posited onto the host plant and were transferred to healthy oat plants. Two weeks before the infestation, the insects were transferred to wheat cultivars to be evaluated, in order to become acquainted with their hosts. Adults and last instars were used in the experiments. When plants reached the desired phenological stage, they were identified, infested, and individually protected in cylindrical cages (55 cm high $\times 7 \mathrm{~cm}$ in diameter) made of transparent acetate. They had a top and two side openings covered with a fine mesh fabric for ventilation.

To assess the population growth of $R$. padi, the number of individuals per plant were evaluated every $48 \mathrm{~h}$. At the end of the 16-day period, the cages were removed, and the plants were sprayed with the insecticide dimethoate (50\%) diluted in water $(1 \mathrm{~mL} / \mathrm{L})$ to eliminate the aphids. Thereafter, the plants were systematically and preventively sprayed with the fungicides propiconazole and tebuconazole $(1 \mathrm{~mL} / \mathrm{L})$ to control fungal diseases. The wheat plants remained in the screenhouse until harvesting, when the number and grain weight and thousand kernels weight were determined for each experimental unit.

The statistical analysis was performed using the software Assistat (Silva \& Azevedo 2009). For each phenological stage, the population growth curves of $R$. padi on the cultivars were compared using the confidence interval (95\%), calculated for each evaluation (days after infestation). The significance of the effect of populations of $R$. padi on grain weight, grain number, and thousand kernels weight, for each cultivar, was performed by ANOVA and means subjected to comparisons by the Tukey test ( $\alpha=5 \%$ ) using the relative loss [Loss $\%=$ (control plant - infested plant) / control plant*100] observed in each variable.

The aphid-day was estimated for the 16-day period. As aphid population increased over time in the present study, better estimation of aphid-days were obtained by the equation proposed by Campbell \& Madden (1990). In this way, the areas under the curve of population growth (AUCPG) were calculated based on the sum of the areas for different time intervals throughout this period, using the following formula:

$A U C P G=\sum_{i}^{n-1}\left[\frac{\left(y_{i}+y_{i+1}\right)}{2}\right]\left[\left(t_{i+1}-t_{i}\right)\right]$

Where $\mathrm{y}_{\mathrm{i}}=$ number of aphids in the $i$ th observation, $\mathrm{t}_{\mathrm{i}}=$ time in the $i$ th observation, and $n=$ total number of observations.

\section{Results and Discussion}

Population growth of $R$. padi

At the tillering stage, the lowest population growth of $R$. padi was observed on the BRS Timbaúva, which differed from other cultivars from the eighth day after infestation (Fig 1a). The colonies formed by $R$. padi on BRS Guabiju and Embrapa 16 showed similar growth, being higher on Embrapa 16 only by the sixteenth day. In the elongation stage, the BRS Timbaúva presented the smallest aphid population (significant statistical difference from the fourth day), maintaining this profile until the end of the evaluation period (Fig 1b). From the eighth day, the population of $R$. padi on the Embrapa 16 was larger than on other cultivars, except for 
Fig 1 Population growth of Rhopalosiphum padi on three wheat cultivars from the initial infestation of 40 aphids/plant, at stages of tillering (a) and elongation (b) over 16 days. (bars $=95 \%$ confidence interval).

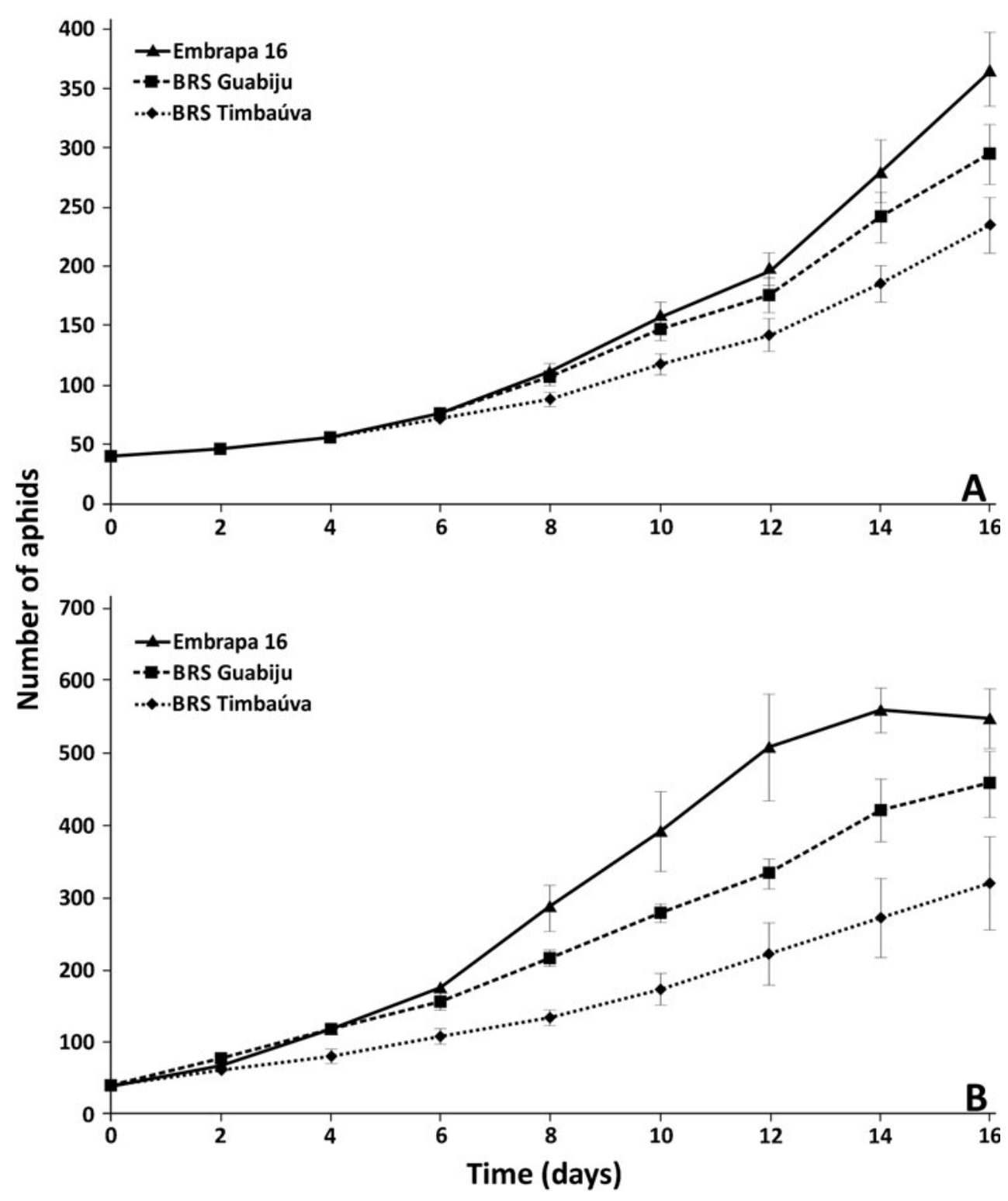

the BRS Guabiju on the sixteenth day after infestation. In both experiments, regardless of the phenological stage, the growth rate of $R$. padi was lower on the BRS Timbaúva, intermediate on the BRS Guabiju, and higher on the Embrapa 16.

The slower growth of $R$. padi on the BRS Timbaúva is an evidence of antibiosis (Painter 1951). This result corroborates the findings of Cezare et al (2011), who observed a decrease in fecundity of $R$. padi on this cultivar with respect to Embrapa 16. There are reports demonstrating antibiosis in wheat genotypes to $R$. padi, as these genotypes prolonged the developmental period and/or reduced the population growth rate of this aphid (Wiktelius \& Pettersson 1985, Razmjou et al 2012). The antibiosis-type resistance, expressed by the smaller number of offspring per female of $R$. padi, was reported by other authors on wheat, rye, and triticale (Kieckhefer \& Kantack 1980, Hesler 2005, Razmjou et al 2012).
Yield

All tested cultivars presented a decline in grain production when compared with non-infested plants when infestation occurred at the stage of tillering. However, reduction in grain weight was lowest for the BRS Timbaúva (17.4\% loss) (Table 1), which may be due to the slower aphid population growth or to its greater tolerance to $R$. padi. The decrease in the weight of the grain of Embrapa 16 was $24.4 \%$, contrasting with the weight of the BRS Guabiju grain, which showed the greatest reduction (30.0\% loss).

The effect of aphids on the number of grains per spike followed the same pattern observed for grain weight. The most significant losses were observed for the BRS Guabiju (24.3\%), followed by Embrapa 16 (20.2\%), and the BRS Timbaúva (13.1\%). 
Table 1 Grain weight (g), grain number, thousand kernels weight (g) (mean \pm SE), and respective differences (loss \%) between plants infested and not infested with Rhopalosiphum padi in three wheat cultivars at the stage of tillering.

\begin{tabular}{|c|c|c|c|}
\hline Cultivars ${ }^{(1,2)}$ & Grain weight (g) & Grain number & $\begin{array}{l}\text { Thousand } \\
\text { kernels weight (g) }\end{array}$ \\
\hline \multicolumn{4}{|l|}{ BRS Guabiju } \\
\hline Non-infested & $27.7 \pm 1.27 \mathrm{a}$ & $805.7 \pm 33.11 \mathrm{a}$ & $34.5 \pm 1.10 \mathrm{a}$ \\
\hline Infested & $19.4 \pm 0.62 b$ & $609.2 \pm 26.38 \mathrm{~b}$ & $31.2 \pm 0.65 b$ \\
\hline Loss \% & $30.0 \mathrm{c}$ & $24.3 \mathrm{C}$ & $9.5 \mathrm{~b}$ \\
\hline \multicolumn{4}{|l|}{ BRS Timbaúva } \\
\hline Non-infested & $30.3 \pm 1.22 \mathrm{a}$ & $953.5 \pm 50.27 a$ & $32.5 \pm 0.93 a$ \\
\hline Infested & $25.0 \pm 0.91 b$ & $828.8 \pm 32.04 b$ & $30.3 \pm 0.82 \mathrm{a}$ \\
\hline Loss $\%$ & $17.4 \mathrm{a}$ & $13.1 \mathrm{a}$ & $6.6 \mathrm{a}$ \\
\hline \multicolumn{4}{|l|}{ Embrapa 16} \\
\hline Non-infested & $31.6 \pm 0.98 \mathrm{a}$ & $900.9 \pm 25.51 \mathrm{a}$ & $35.1 \pm 0.55 a$ \\
\hline Infested & $23.9 \pm 0.72 b$ & $718.0 \pm 12.30 \mathrm{~b}$ & $32.7 \pm 0.76 \mathrm{~b}$ \\
\hline Loss $\%$ & $24.4 \mathrm{~b}$ & $20.2 \mathrm{~b}$ & $6.8 \mathrm{a}$ \\
\hline
\end{tabular}

(1) Means followed by same letter do not differ by t test (comparison of the cultivar with and without infestation) and Tukey's test (comparison of the reduction between cultivars) $(P>0.05)$.

(2) Infestation for 16 days beginning with 40 aphids/plant.

Regarding the weight of thousand kernels, the BRS Timbaúva and Embrapa 16 cultivars were statistically similar, with losses of 6.6 and $6.8 \%$, respectively. These cultivars differed from the BRS Guabiju, which showed the greatest reduction in the thousand kernels weight due to aphid infestation (9.5\%).

As observed during tillering, the infestation in the elongation stage caused significant reduction in the grain yield of the three cultivars. The BRS Timbaúva had the smallest reduction in grain weight (damage of $24.9 \%$ ), followed by Embrapa 16 (26.8\%), and BRS Guabiju (32.2\%) (Table 2).

The effect of aphid infestation during the elongation stage on the number of grains (Table 2), as happened for the tillering stage, was lower for the BRS Timbaúva, which decreased by $19.2 \%$, differing from the other cultivars. The BRS Guabiju and Embrapa 16 were statistically similar, with a reduction of 30.5 and $28.6 \%$, respectively.

For the variable weight of thousand kernels, the differences between cultivars became more pronounced (Table 2). They all differed from one other, and the BRS Timbaúva was the least damaged ( $7.8 \%$ loss) when compared with Embrapa 16 (9.7\%) and BRS Guabiju (13.3\%).

The population growth of $R$. padi and the reduction in grain yield were consistently lower for the BRS Timbaúva in both experiments. The least damage suffered by this cultivar is mainly due to its ability to slow down the aphid population growth. The Embrapa 16 was more tolerant than then BRS Guabiju. Even though it allowed a greater aphid population growth, the former suffered a smaller reduction in grain yield.
Table 2 Grain weight (g), grain number, thousand kernel weight (g) (mean $\pm S E$ ), and respective differences (loss \%) between plants infested and not infested with Rhopalosiphum padi in three wheat cultivars at the stage of elongation.

\begin{tabular}{lll}
\hline Cultivars $^{(1,2)} \quad$ Grain weight $(g) \quad$ Grain number & $\begin{array}{l}\text { Thousand } \\
\text { kernel weight }(g)\end{array}$
\end{tabular}

$\begin{array}{llll}\text { BRS Guabiju } & & & \\ \text { Non-infested } & 15.6 \pm 0.61 \mathrm{a} & 555.5 \pm 17.74 \mathrm{a} & 33.7 \pm 0.28 \mathrm{a} \\ \text { Infested } & 10.6 \pm 0.42 \mathrm{~b} & 385.3 \pm 12.56 \mathrm{~b} & 29.2 \pm 0.46 \mathrm{~b} \\ \text { Loss \% } & \mathbf{3 2 . 2} \mathrm{C} & \mathbf{3 0 . 5} \mathbf{b} & \mathbf{1 3 . 3} \mathbf{~ C} \\ \text { BRS Timbaúva } & & & \\ \text { Non-infested } & 19.0 \pm 0.52 \mathrm{a} & 626.5 \pm 17.61 \mathrm{a} & 32.0 \pm 0.22 \mathrm{a} \\ \text { Infested } & 14.3 \pm 0.43 \mathrm{~b} & 505.8 \pm 13.08 \mathrm{~b} & 29.5 \pm 0.24 \mathrm{~b} \\ \text { Loss \% } & \mathbf{2 4 . 9} \mathrm{a} & \mathbf{1 9 . 2} \mathrm{a} & \mathbf{7 . 8} \mathrm{a} \\ \text { Embrapa 16 } & & & \\ \text { Non-infested } & 17.0 \pm 0.64 \mathrm{a} & 559.2 \pm 15.24 \mathrm{a} & 31.9 \pm 0.48 \mathrm{a} \\ \text { Infested } & 12.4 \pm 0.43 \mathrm{~b} & 400.2 \pm 14.11 \mathrm{~b} & 28.8 \pm 0.43 \mathrm{~b} \\ \text { Loss \% } & \mathbf{2 6 . 8 ~ b} & \mathbf{2 8 . 6} \mathbf{b} & \mathbf{9 . 7} \mathbf{b}\end{array}$

(1) Means followed by same letter do not differ by $t$ test (comparison of the cultivar with and without infestation) and Tukey's test (comparison of the reduction between cultivars) $(P>0.05)$.

(2) Infestation for 16 days beginning with 40 aphids/plant.

Our results are consistent with those obtained by Peruzzo et al (2007), who observed differences in grain yield among wheat cultivars infested with $R$. padi which was less pronounced on BRS Timbaúva than on BRS Guabiju. Tolerance to the aphid $R$. padi by the BRS Timbaúva with respect to the BRS Guabiju needs to be confirmed by specific assays comparing yields under infestation with the same number of insects.

Populations of $R$. padi were larger during elongation than during tillering, which can be explained by the higher carrying capacity of more developed plants. Although the comparison between absolute numbers suggests that aphid infestation during the elongation stage caused more damage than infestation during tillering, when the data were corrected for the number of aphids per time interval (aphid-day), the

Table 3 Aphid-day (AD) and reduction in grain weight observed (loss \%) and corrected (L\%/AD) in three cultivars of wheat infested with Rhopalosiphum padi at two phenological stages.

\begin{tabular}{|c|c|c|c|c|c|c|}
\hline \multirow[t]{3}{*}{ Cultivars } & \multicolumn{6}{|l|}{ Stages } \\
\hline & \multicolumn{3}{|l|}{ Tillering } & \multicolumn{3}{|c|}{ Elongation } \\
\hline & $A D$ & Loss $\%$ & $L \% / A D$ & $A D$ & Loss $\%$ & $L \% / A D$ \\
\hline BRS Guabiju & $2,032.30$ & 30.0 & 0.015 & 3672.65 & 32.2 & 0.009 \\
\hline BRS Timbaúva & $1,690.16$ & 17.4 & 0.010 & 2450.95 & 24.9 & 0.010 \\
\hline Embrapa 16 & $2,254.96$ & 24.4 & 0.011 & 4774.1 & 26.8 & 0.006 \\
\hline
\end{tabular}

$L \% / A D$ loss $\%$ per aphid-day, which estimates the damage caused by 1 aphid-day. 
damage was slightly higher in the tillering than in the elongation stage, except for the BRS Timbaúva, the least damaged cultivar (Table 3). Damage due to 100 aphid-days was around $1 \%$ reduction in grain weight per plant. The results of these experiments suggest that a deeper insight on the response of wheat cultivars to this species of aphid may lead to an adjustment in the aphid control levels recommended for each cultivar (RCBPTT 2010).

Population growth and loss in grain yield by $R$. padi were less significant on the BRS Timbaúva cultivar when compared with BRS Guabiju and Embrapa 16, when infestation occurred at the stages of tillering and elongation. The wheat cultivar Embrapa 16 is more tolerant than the BRS Guabiju to the damage caused by infestations of $R$. padi on the phenological stages of tillering and elongation.

The biochemical and physiological causes involved on this type of resistance need to be investigated. The knowledge of these characteristics may be helpful when used in wheat breeding programs in order to enhance the level of resistance/tolerance of new materials to $R$. padi. The adoption of aphid-resistant cultivars in wheat crops will be an important tool to be used in integrated pest management programs.

Acknowledgments We thank Embrapa Trigo for the support in conducting the experiments. We also thank the "Programa de PósGraduação em Agronomia"-PPGAgro, at the Universidade de Passo Fundo, RS. M Savaris acknowledge the grant support from "Coordenação de Aperfeiçoamento de Pessoal de Nível Superior"-CAPES.

\section{References}

Campbell CL, Madden LV (1990) Introduction to plant disease epidemiology. John Willey \& Sons, New York, $532 p$

Cezare DG, Schons J, Lau D (2011) Analysis of resistance/tolerance of the wheat cultivar BRS Timbaúva to Barley yellow dwarf virus (BYDVPAV). Trop Plant Pathol 36:249-255

Gassen DN (1984) Insetos associados à cultura do trigo no Brasil. Passo Fundo, EMBRAPA - CNPT, 39p. (Circular Técnica, 3)

Gomes MFR, Salvadori JR, Schons J (2008) Danos de Rhopalosiphum padi (L.) (Hemiptera: Aphididae) no trigo em função da duração e da densidade de infestação. Neotrop Entomol 37:577-581
Hesler LS (2005) Resistance to Rhopalosiphum padi (Homoptera: Aphididae) in three triticale accessions. J Econ Entomol 98:603-610

Kieckhefer RW, Kantack BH (1980) Losses in yield in spring wheat in south Dakota caused by cereal aphids. J Econ Entomol 73:582-585

Kieckhefer RW, Kantack BH (1988) Yield losses in winter grains caused by cereal aphids (Homoptera: Aphidade) in South Dakota. J Econ Entomol 81:317-321

Large EC (1954) Growth stages in cereals. Illustration of Feekes Scale. Plant Pathol 3:128-129

Painter RH (1951) Insect resistance in crop plants. Mac Millan, New York, $520 \mathrm{p}$

Pereira PRVS, Salvadori JR, Lau D (2008) Pulgão-preto-dos-cereais, Sipha maydis Passerini, 1860 (Hemiptera: Aphididae). Passo Fundo: Embrapa Trigo, 1 folder

Peruzzo R, Salvadori JR, Pereira PRVS, Bertollo EC, Tonello LS (2007) Resposta de cultivares de trigo à infestação do pulgão Rhopalosiphum padi. Pesq Agropec Bras 42:1681-1685

Parizoto G, Rebonatto A, Schons J, Lau D (2013) Barley yellow dwarf virus-PAV in Brazil: seasonal fluctuation and biological characteristics. Trop Plant Pathol 38:11-19

Razmjou J, Mohamadi P, Golizadeh A, Hasanpour M, Naseri B (2012) Resistance of wheat lines to Rhopalosiphum padi (Hemiptera: Aphididae) under laboratory conditions. J Econ Entomol 105:592-597

RCBPTT (2010) Reunião da Comissão Brasileira de Pesquisa de Trigo e Triticale Informações técnicas para trigo e triticale - safra 2011. Cascavel: COODETEC. Comissão Brasileira de Pesquisa de Trigo e Triticale $170 \mathrm{p}$

Salvadori JR (2000) Pragas de trigo no Brasil, p. 155-167. In: Guedes JC, da Costa ID, Castiglioni E (eds) Bases e técnicas do manejo de insetos. Ed Pallotti, Santa Maria, $248 p$

Salvadori JR, Tonet GEL (2001) Manejo integrado dos pulgões de trigo. Passo Fundo, EMBRAPA - CNPT, 52p. (Documentos, 34)

Salvadori JR, de Salles LAB (2002) Controle biológico de pulgões do trigo, p.427-447. In: Parra JRP, Botelho PSM, Corrêa-ferreira BS, Bento JMS (eds) Controle biológico no Brasil: parasitóides e predadores. Manole, São Paulo, $626 \mathrm{p}$

Salvadori JR, Pereira PRVS, Voss M (2006) Controle biológico de pragas do trigo, p.55-63. In: Pinto A de S, Nava DE, Rossi MM, Malerbo-souza DT (eds) Controle biológico de pragas. Piracicaba, CP2, $287 \mathrm{p}$

Silva F de AS, Azevedo CAV de (2009) Principal components analysis in the software Assistat-Statistical Attendance. In: World Congress on Computers in Agriculture Conference, 7., Reno, NV, USA. Proceedings... Reno: American Society of Agricultural and Biological Engineers

Voss TS, Kieckhefer RW, Fuller BW, Mcleod MJ, Beck DA (1997) Yield losses in maturing spring wheat caused by cereal APHIDS (Homoptera: Aphididae) under laboratory conditions. J Econ Entomol 90:1346-1350

Wiktelius S, Pettersson J (1985) Simulations of bird cherry-oat aphid population dynamics a tool for developing strategies for breeding aphid-resistant plants. Agric Ecosyst Environ 14:159-170 